University of Nebraska - Lincoln

DigitalCommons@University of Nebraska - Lincoln

Paleoceanographic History of the Guaymas Basin, Gulf of California, During the Past 15,000 Years Based on Diatoms, Silicoflagellates, and Biogenic Sediments

John A. Barron

U.S. Geological Survey, MS910, Menlo Park, CA 94025, United States

David Bukrya

U.S. Geological Survey, MS910, Menlo Park, CA 94025, United States

Walter E. Dean

U.S. Geological Survey, Denver, CO, dean@usgs.gov

Follow this and additional works at: https://digitalcommons.unl.edu/usgsstaffpub

Part of the Earth Sciences Commons

Barron, John A.; Bukrya, David; and Dean, Walter E., "Paleoceanographic History of the Guaymas Basin, Gulf of California, During the Past 15,000 Years Based on Diatoms, Silicoflagellates, and Biogenic Sediments" (2005). USGS Staff -- Published Research. 327.

https://digitalcommons.unl.edu/usgsstaffpub/327

This Article is brought to you for free and open access by the US Geological Survey at DigitalCommons@University of Nebraska - Lincoln. It has been accepted for inclusion in USGS Staff -- Published Research by an authorized administrator of DigitalCommons@University of Nebraska - Lincoln. 


\title{
Paleoceanographic history of the Guaymas Basin, Gulf of California, during the past 15,000 years based on diatoms, silicoflagellates, and biogenic sediments
}

\author{
John A. Barron ${ }^{\mathrm{a}, *}$, David Bukry ${ }^{\mathrm{a}}$, Walter E. Dean ${ }^{\mathrm{b}}$ \\ ${ }^{a}$ U.S. Geological Survey, MS910, Menlo Park, CA 94025, United States \\ ${ }^{\mathrm{b}}$ U.S. Geological Survey, MS 980, Federal Center, PO Box 25046, Denver, CO 80225, United States
}

Received 4 January 2005; received in revised form 30 March 2005; accepted 1 April 2005

\begin{abstract}
High-resolution records of calcium carbonate, biogenic opal, diatoms, and silicoflagellates from western Guaymas Basin gravity core GGC55 and piston core JPC56 and eastern Guaymas Basin DSDP Site 480 reveal a complex paleoceanographic history of the central Gulf of California during the past 15,000 years. Prior to $\sim 6.2 \mathrm{ka}$, the eastern and western Guaymas Basin proxy records were remarkably similar. After conditions similar to those of today during the Bølling-Allerod, the Younger Dryas (YD) saw a major drop in diatom production, coincident with increased calcium carbonate and tropical microfossils suggestive of El Niño-like conditions. Biosiliceous productivity began increasing during the latter part of the YD, but it was only during the earliest Holocene (11.6 to $11.0 \mathrm{ka}$ ) that conditions similar to those of the Bølling-Allerod returned to the central Gulf. Between around 11.0 and $6.2 \mathrm{ka}$, tropical diatoms and silicoflagellates were virtually absent from the central Gulf, as relatively cooler and fresher surface waters resembling those of the modern northern Gulf were present in the central Gulf. Beginning at about $6.2 \mathrm{ka}$, tropical diatoms and silicoflagellates began increasing in the central Gulf, and coccoliths returned to western Gulf sediments. The onset of modern-day monsoon conditions in the American Southwest required the presence of warm SSTs in the northern Gulf, which probably did not occur until after about 5.4 ka, when tropical diatoms and silicoflagellates became relatively common in the central Gulf. Modern east-west contrasts, which arise from late winterearly spring coastal upwelling on the mainland side and lower diatom productivity on the western side of the Gulf, commenced between 6.2 and $5.4 \mathrm{ka}$, possibly due to a shift in the direction of late winter-early spring winds more towards the southeast, or down the axis of the Gulf. This proposed wind shift might have ultimately been due to a late Holocene strengthening of ENSOlike conditions in the eastern equatorial Pacific.
\end{abstract}

Published by Elsevier B.V.

Keywords: Holocene; El Niño; Gulf of California; Upwelling; Diatoms; Silicoflagellates; Opal

\footnotetext{
* Corresponding author.

E-mail address: jbarron@usgs.gov (J.A. Barron).
}

0377-8398/\$ - see front matter. Published by Elsevier B.V. doi:10.1016/j.marmicro.2005.04.001

This article is a U.S. government work, and is not subject to copyright in the United States. 


\section{Introduction}

\subsection{Gulf of California climatology}

The geographic setting of the Gulf of California (referred to as the "Gulf" throughout this paper) and the widespread occurrence of varved sediments in the depth range between 500 and $900 \mathrm{~m}$ on the slopes of its basins make it ideal for paleoceanographic studies. Gulf region climate contains a mid-latitude winter phase and a subtropical summer phase. During late fall to early spring (November to March), prevailing surface winds are northwesterly, along the mean pressure gradient, causing an overturn of the water column, upwelling of nutrients and enhanced phytoplankton production (Bandon-Dangon et al., 1991). Although it has traditionally been thought that summer (July to September) winds blow from the south, Pares-Sierra et al. (2002) recently demonstrated that the summer reversal in wind direction occurs only in the southern part of the Gulf. Throughout the central part of the Gulf, including the Guaymas Basin, a slackening of northwest winds is more typical of the summer. Nevertheless, based on the presence of regular rainfall and increased influence of tropical waters during the summer, the central Gulf region is usually regarded to have a monsoonal climate (Mitchell et al., 2002).

Sediment trap studies in the Guaymas and Carmen basins (Thunell et al., 1994, 1996; Thunell, 1998) reveal that the peak flux in biogenic silica, which is overwhelmingly diatoms, occurs in November and December (the "fall dump" by Kemp et al., 2000), coincident with the onset of northwest winds. A second peak in diatom flux occurs during the late winter to early spring (February to March; Thunell et al., 1994), coincident with a period of coastal upwelling, which is stronger along the mainland coast than it is off the coast of Baja California (Santamaria-del-Angel et al., 1994). Thunell (1998) noted that this late winter to early spring flux is relatively small in magnitude compared to that of the late fall, and he speculated that grazing by zooplankton might be responsible for this.

A well-developed oxygen minimum zone (OMZ) is present throughout the southern and central Gulf between 500 and 800-1000 (Bandon-Dangon et al., 1991). The OMZ in the Gulf is enhanced by high productivity in overlying surface waters which leads to increased oxygen consumption by consumers. As low oxygen bottom waters prevent burrowing by sea floor organisms, sediments deposited within the OMZ are typically varved, making them excellent for highresolution paleoceanographic studies.

\subsection{Previous paleoceanographic studies}

Barron et al. (2004) used diatoms, silicoflagellates, and geochemistry at DSDP Site $480\left(27^{\circ} 54.10^{\prime} \mathrm{N}\right.$, $111^{\circ} 39.34^{\prime} \mathrm{W}, 655 \mathrm{~m}$ water depth) to construct a high-resolution paleoceanographic record for the eastern Guaymas Basin of the central Gulf during the past 15,000 years. They concluded that (1) the BøllingAllerod interval (14.6-12.9 ka) (note, ka refers to 1000 calendar years B.P. throughout this report) was characterized by an increase in biogenic silica and a decline in calcium carbonate, suggesting conditions somewhat similar to those of today; (2) the Younger Dryas (12.9-11.6 ka) was marked by a major drop in biogenic silica and an increase in calcium carbonate, suggesting a reduction of upwelling of nutrient-rich waters; (3) between 10.6 and $10.0 \mathrm{ka}$, calcium carbonate (mostly from coccoliths) and the tropical diatom Azpeitia nodulifera abruptly declined, while Roperia tesselata, a modern-day indicator of winter upwelling in the modern-day Gulf, increased sharply in numbers; (4) at about $6.2 \mathrm{ka}$ a stepwise increase in biogenic silica and the reappearance of the tropical diatom A. nodulifera marked a major change in oceanographic conditions in the Gulf; and (5) beginning between 2.8 and $2.4 \mathrm{ka}$, the amplitude of biogenic silica and wt.\% Fe, $\mathrm{Al}$, and $\mathrm{Ti}$ increased, possibly due to an intensification of ENSO cycles and the establishment of modern oceanographic conditions in the Gulf (Fig. 1).

Barron et al.'s (2004) conclusions relied heavily on the studies of Sancetta (1995), who used sediment trap data to interpret downcore diatom data of the past 15,000 years in piston core JPC56 $\left(27.5^{\circ} \mathrm{N}\right.$, $112.1^{\circ} \mathrm{W}$, water depth $818 \mathrm{~m}$ ) in the western Guaymas Basin. In addition to making similar conclusions about the Bølling-Allerod and YD, as Barron et al. (2004) later made, Sancetta (1995) suggested that low spring diatom production that began in the YD persisted into the Holocene, while winter winds gradually increased, peaking in the middle part of the Holocene. 
a

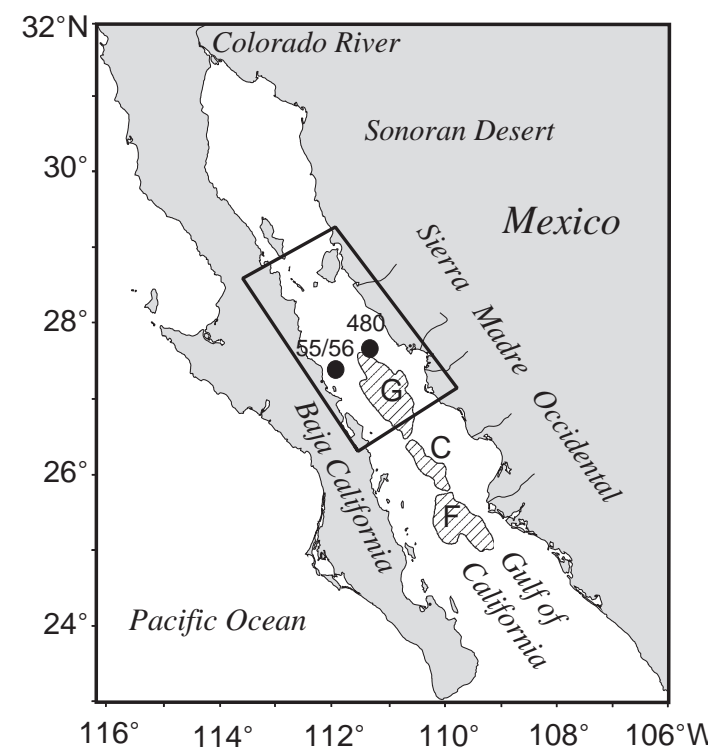

b

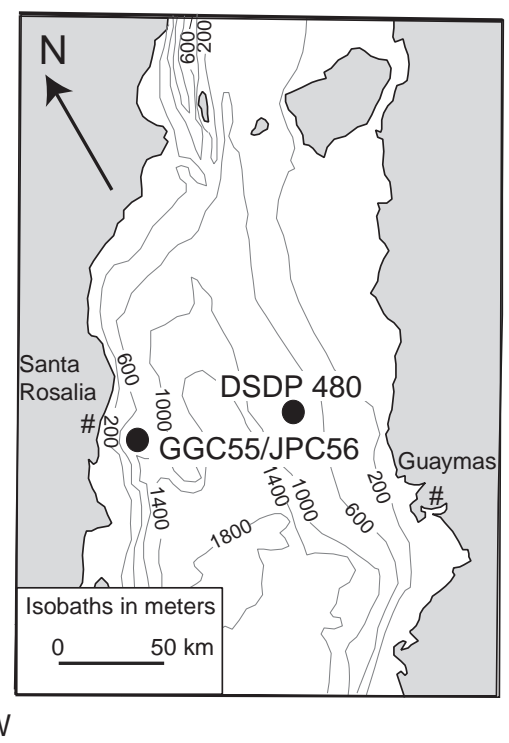

Fig. 1. (a) Location of GGC55/JPC56 and DSDP 480 Guaymas Basin of the Gulf of California. Areas marked by diagonal lines represent closed basins below the 1500-m depth contour. G-Guaymas Basin, C-Carmen Basin; F-Farallon Basin. (b) Smaller scale map of the northern Guaymas Basin and its margins, showing core locations and depth contours at 200-m intervals.

An important paleoceanographic study completed on piston core JPC56 is that of Pride et al. (1999), who studied the opal content and nitrogen isotopes from a composite section of the past 16,000 years made up of piston core JC56 and nearby gravity core GGC-55 $\left(27^{\circ} 28.22^{\prime} \mathrm{N}, 112^{\circ} 6.33^{\prime} \mathrm{W}\right.$, water depth $\left.820 \mathrm{~m}\right)$. These authors pointed out that homogeneous sediment with relatively low opal content was deposited during the end of the last glacial period, the YD, and the middle and late Holocene, whereas laminated sediment with high opal content was deposited during the Bølling-Allerod and early Holocene. Pride et al. (1999) noted that the nitrogen isotopic composition of organic matter $\left(\delta^{15} \mathrm{~N}_{\text {org }}\right)$ was higher in laminated sediments that contained a higher opal content and lower in the homogeneous sediments that were characterized by lower opal content. They attributed abrupt shifts in $\delta{ }^{15} \mathrm{~N}_{\text {org }}$ and sediment fabric to widespread changes in the extent of suboxic subsurface waters, which they suggested were amplified in the central Gulf due to variations in the strength of upwelling associated with vertical mixing and/or the latitudinal position of the Intertropical Convergence Zone (ITCZ).

More recently, Keigwin (2002) studied the oxygen and carbon isotopes of planktic and benthic forami- nifers of the late glacial and Holocene of the GGC55/JPC56 composite section and found that benthic $\delta^{18} \mathrm{O}$ increased continually throughout the GGC55/JP56 record, without obvious pauses or reversals such as during the YD. He recorded low $\delta^{13} \mathrm{C}$ for the benthic foraminifer Planulina ariminensis and the planktic foraminifers Neogloboquadrina pachyderma and Globigerina bulloides during the Bølling-Allerod and early Holocene, which he attributed to menthane release during these warm climatic intervals. Keigwin (2002) also observed a pronounced positive shift in the $\delta^{13} \mathrm{C}$ of $N$. pachyderma at about $6 \mathrm{ka}$ that coincided with a return to bioturbated sediments and a drop in opal accumulation rates reported by Pride et al. (1999) in the GGC55/ JP56 record.

Given these recent studies on GGC55 and JPC56 in the western Guaymas Basin, it is appropriate to complete a high-resolution study of the diatoms, silicoflagellates, and geochemistry of these cores, using comparable methods as those used by Barron et al.(2004) at DSDP 480 (data archived at ftp://ftp. ncdc.noaa.gov/pub/data/paleo/contributions_by_author/ barron2004/). The results of such a study will reveal both similarities and east-west differences in the bio- 
genic proxy record of the central Gulf that are important in understanding the region's complex paleoceanographic evolution.

\section{Materials and methods}

\subsection{Age model}

The chronology for GGC55 and JPC56 is after Keigwin (2002), who recalibrated the results of Pride et al. (1999) using the revised reservoir correction of 725 years ( $\partial R=395$ years) for the central Gulf (Goodfriend and Flessa, 1997; Table 1).

Based on the nearly equivalent calendar ages obtained on planktic foraminifers from the 319- to $321-\mathrm{cm}$ interval of GGC55 and those from the 99- to $101-\mathrm{cm}$ interval of JPC56 (5580 and $5588 \mathrm{cal}$ years B.P., respectively), we conclude that the records from GGC55 can be spliced together with those of JPC56 by assuming that the $0-\mathrm{cm}$ interval of JPC 56 coincides with the 220-cm horizon in GGC55. Thus, 220 $\mathrm{cm}$ has been added to the depth of samples taken from JPC56 in our composite section. This $220-\mathrm{cm}$ offset is less than the 150 -cm offset suggested by Keigwin (2002), that apparently based on his isotope results.
An age vs. depth plot of the composite record of GGC55 and JPC56 is shown on Fig. 2. Sediment accumulation rates average around $88 \mathrm{~cm} / \mathrm{kyr}$ for the past 10,000 years. This rate and the $2.77 \mathrm{ka}$ calendar date on planktic foraminifers from the 59- to 61$\mathrm{cm}$ interval of GGC55, imply that the last 2100 years are missing from the top of the GGC55 record. Prior to $10 \mathrm{ka}$, sediment accumulation rates were generally much higher, ca. $250 \mathrm{~cm} / \mathrm{kyr}$, with the exception of an interval of reduced rates (ca. $111 \mathrm{~cm} / \mathrm{kyr}$ ) that occurred between roughly 13.4 and $11.6 \mathrm{ka}$.

At DSDP 480 sediment accumulation rates were much lower $(\sim 55$ to $112 \mathrm{~cm} / \mathrm{kyr})$ than those at GGC55/JPC56 prior to $\sim 10 \mathrm{ka}$, but somewhat higher $(\sim 114 \mathrm{~cm} / \mathrm{kyr})$ after $10 \mathrm{ka}$ (Barron et al., 2004).

\subsection{Sampling}

Splits of samples taken by Dean (in press), at 10$\mathrm{cm}$ intervals from cores GGC55 and JPC56), were studied for diatoms and silicoflagellates. Sample spacing ranges between $\sim 110$ years during the past 10,000 years to close to 60 years during the period prior to around $13 \mathrm{ka}$ and for parts of the earliest Holocene. The approximate $1-\mathrm{cm}$ thickness of each sample and the varved nature of most of the sediments suggest

Table 1

Radiocarbon results of Keigwin (2002) for GGC55 an JPC56

\begin{tabular}{|c|c|c|c|c|c|c|c|c|}
\hline Depth $(\mathrm{cm})$ & $\begin{array}{l}\text { Average } \\
\text { depth }(\mathrm{cm})\end{array}$ & $\begin{array}{l}\text { Composite } \\
\text { depth }(\mathrm{cm})\end{array}$ & $\begin{array}{l}\mathrm{PF}{ }^{14} \mathrm{C} \text { age } \\
\text { (years) }\end{array}$ & $\begin{array}{l}\begin{array}{l}\text { Error } \\
\text { (years) }\end{array} \\
\end{array}$ & $\begin{array}{l}\text { PF Calib } \\
\text { age (years) }\end{array}$ & $\begin{array}{l}\mathrm{BF}{ }^{14} \mathrm{C} \text { age } \\
\text { (years) }\end{array}$ & $\begin{array}{l}\begin{array}{l}\text { Error } \\
\text { (years) }\end{array} \\
\end{array}$ & $\begin{array}{l}\text { BF Calib } \\
\text { age (years) }\end{array}$ \\
\hline \multicolumn{9}{|l|}{ GGC55 } \\
\hline $59-61$ & 60 & 60 & 3420 & 35 & 2770 & 4080 & 30 & 3591 \\
\hline $209-211$ & 210 & 210 & 4710 & 40 & 4418 & 5220 & 25 & 5072 \\
\hline $319-321$ & 320 & 320 & 5610 & 45 & 5580 & 6130 & 35 & 6165 \\
\hline \multicolumn{9}{|l|}{ JPC56 } \\
\hline 99-101 & 100 & 320 & 5630 & 60 & 5588 & 6170 & 35 & 6190 \\
\hline $419-421$ & 420 & 640 & 9355 & 70 & 9597 & 9280 & 55 & 9449 \\
\hline $469-471$ & 470 & 690 & 9705 & 75 & 9900 & 9520 & 45 & 9807 \\
\hline $649-651$ & 650 & 870 & 10,125 & 80 & 10,330 & 10,550 & 60 & 11,114 \\
\hline 899-901 & 900 & 1120 & 10,945 & 75 & 11,653 & 11,350 & 45 & 12,495 \\
\hline 999-1001 & 1000 & 1220 & 11,490 & 90 & 12,735 & 12,050 & 45 & 13,146 \\
\hline 1099-1101 & 1100 & 1320 & 12,395 & 80 & 13,457 & 12,950 & 60 & 14,085 \\
\hline $1399-1401$ & 1400 & 1620 & 13,400 & 90 & 14,722 & 13,950 & 55 & 15,696 \\
\hline $1599-1601$ & 1600 & 1820 & 13,685 & 100 & 15,431 & 14,150 & 55 & 15,931 \\
\hline $1699-1701$ & 1700 & 1920 & 14,580 & 100 & 16,427 & 14,700 & 65 & 16,565 \\
\hline $1849-1851$ & 1850 & 2070 & 14,870 & 100 & 16,761 & 15,550 & 60 & 17,543 \\
\hline
\end{tabular}

$\mathrm{PF}$ - planktic foram; $\mathrm{BF}$ - benthic foram. 


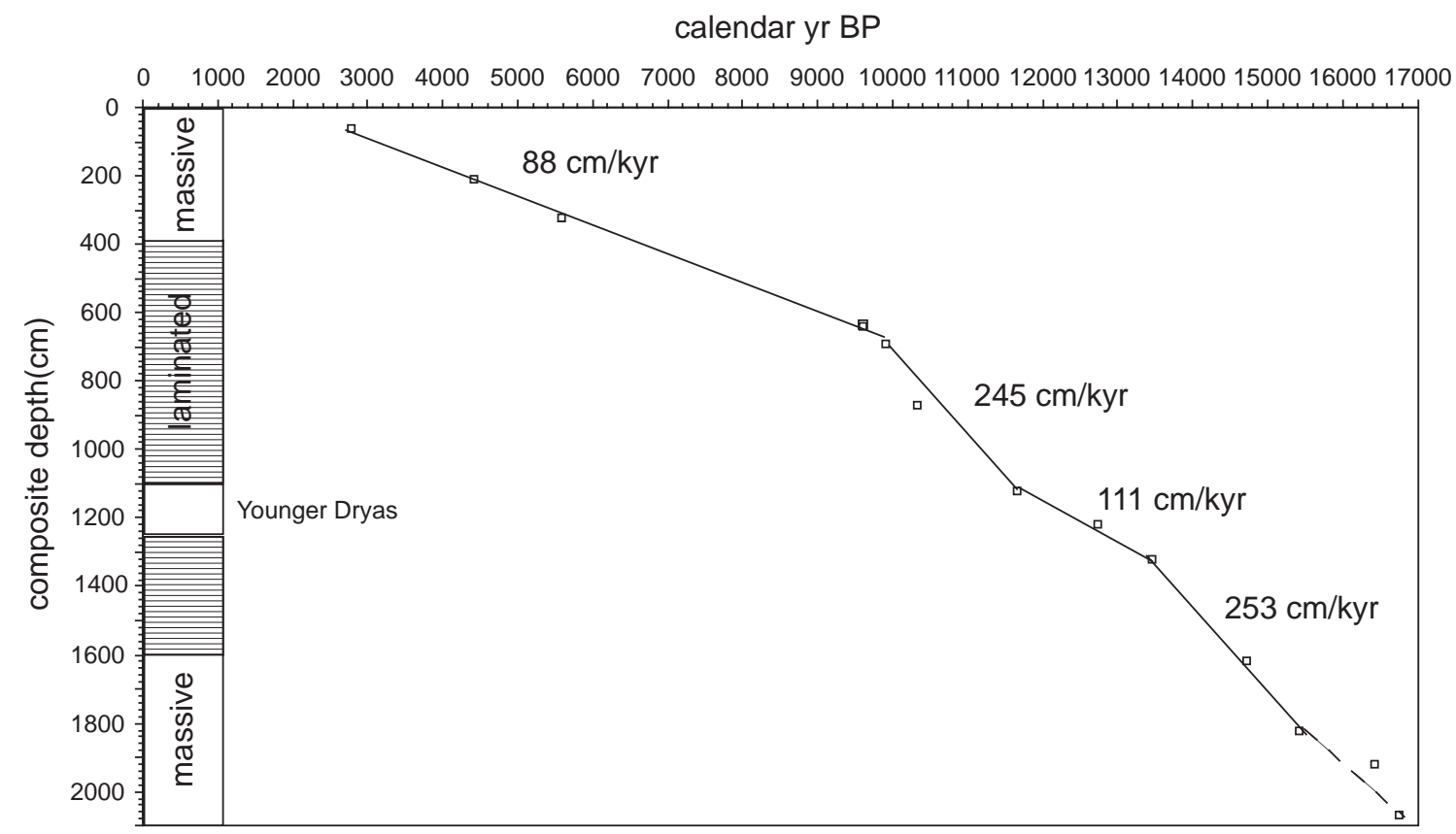

Fig. 2. Age model used for the composite section of GGC55 and JPC56 (Table 1) based on calibrated AMS dates on planktic foraminifers (Keigwin, 2002) and using a splice of $220 \mathrm{~m}$ in GGC55 to the surface of JPC56. Lithologic column after Pride et al. (1999).

that each sample represents a composite of between 4 and 11 years of deposition. Samples were taken vertically across the varves and homogeneous splits were used for siliceous microfossil and geochemical studies. Siliceous microfossil studies extended down through the 1450-cm interval of JPC56 (or about 15 $\mathrm{ka}$ ), so that the results could be compared directly with those from DSDP 480 in the eastern Guaymas Basin.

\subsection{Calcium carbonate and biogenic opal}

Calcium carbonate values for GGC55 and JPC56 were determined using a carbon dioxide coulometer (Dean, in press). Dried and powdered samples were analyzed for weight percentages of total carbon (TC) and total inorganic carbon (IC) using a carbon dioxide coulometer (Engleman et al., 1985). Percent organic carbon (OC) was calculated as the difference (TC-TIC), and percent $\mathrm{CaCO}_{3}$ was calculated as

$\mathrm{CaCO}_{3}=\mathrm{IC} / 0.12$,

where 0.12 is the fraction of carbon in $\mathrm{CaCO}_{3}$. The accuracy and precision of this method, determined from hundreds of replicate standards, are usually better than 0.10 wt. $\%$ for TC and 0.10 wt. $\%$ $(1 \sigma=0.084)$ for TIC. This method is the same as that used by Barron et al. (2004) to estimate calcium carbonate in DSDP 480.

Values of biogenic silica for cores GGC55 and JPC56 are from Pride et al. (1999), following the $\mathrm{Na}_{2} \mathrm{CO}_{3}$ extraction method described by Mortlock and Froelich (1989). Biogenic silica was converted by Pride et al. (1999) to percent opal $\left(\mathrm{SiO}_{2} \cdot \mathrm{nH}_{2} \mathrm{O}\right.$ or biogenic opal) by multiplying the measured percentage of biogenic silica by 2.4 .

This method differs from the method used by Barron et al. (2004) to estimate weight percent biogenic silica in DSDP 480, who used the $\mathrm{Si}$ / Al ratio as determined from bulk ICP-AES geochemical analyses. They assumed that the Si/Al ratio of the detrital fraction at DSDP 480 is the same as Pacific pelagic clay (PPC), or 3.30. In other words, \%Si-detrital $=\% A 1 * 3.30$ and \%Si-biogenic $=(\%$ Si-total $)-(\%$ Si-detrital $)$. The biogenic silica values of Barron et al. (2004) have been converted to biogenic opal for by multiplying them by 2.4 . 


\subsection{Diatoms}

Following Sancetta (1995), counts of diatoms were made under the light microscope at $500 \times$, ignoring Chaetoceros spores and Thalassionema nitzschioides that dominate the sediment assemblages and mask subtle seasonal changes that occur in less common diatom taxa. As in Barron et al. (2004), small and delicate taxa such as Fragilariopsis, Rhizosolenia, and Thalassiosira were also not tabulated so as to reduce bias caused by differential dissolution and differential settling of pipetted samples. Large centric diatoms demonstrating clear environmental preferences according to the sediment trap studies of Sancetta (1995; written communication, 2001), and sediment fabric studies of Pike and Kemp (1997) and Kemp et al. (2000) were counted. These included Actinocyclus curvatulus, A. octonarius, Actinoptychus spp., Azpeitia nodulifera, Coscinodiscus radiatus, Coscinodiscus spp. (mainly large-diameter forms such as C. asteromphalus, C. granii, and C. oculus-iridis), Cyclotella spp. (mainly $C$. littoralis), Roperia tesselata, and Stephanopyxis palmeriana. At least 200 diatoms per sample were counted while making random traverses across the microscope slide (data archived at $\mathrm{ftp} / / / \mathrm{ftp} . n c d c . n o a a . g o v / p u b /$ data/paleo/ contributions_by_author/barron2005/).

\subsection{Silicoflagellates}

Silicoflagellate slides were systematically tracked to obtain a representative count of 200 specimens per sample. Counts were typically made at $250 \times$ magnification, with $500 \times$ used for checking questionable identifications. All whole specimens and half specimens with intact apical structures intact were counted. Smaller fragments were not counted.

Taxa counted included those tabulated by Murray and Schrader (1983), although their taxonomy has been updated and further subdivisions have been recognized. Additional taxa tabulated include D. calida ampliata, a tropical form grouped with $D$. calida by Poelchau (1976) and D. aspinosa, a cosmopolitan form, grouped with D. stapedia by Poelchau (1976). Dictyocha sp. A and B of Murray and Schrader (1983) are tabulated as D. perlaevis, although the $D$. sp. A forms can be distinguished by their more elon- gate appearance, resulting in a minor axis lacking spines on the basal ring. Dictyocha messanensis of Murray and Schrader (1983) is recognized as Dictyocha stapedia. Similarly, Dictyocha epidon of Murray and Schrader (1983) is recognized as D. aculeata. Large specimens of Dictyocha with canted apical bars and slightly bowed basal ring, reminiscent of $D$. aculeata, are recorded as $D$. sp. aff. D. aculeata. These probably represent an endemic Gulf variant of $D$. aculeata, which is associated with the modern California Current. Octactis pulchra specimens were separated into three size categories: (1) larger specimens; (2) medium specimens typically one-half the size of the larger specimens; and (3) small specimens typically one fourth the size of the larger specimens (data archived at ftp://ftp.ncdc.noaa.gov/pub/data/ paleo/contributions_by_author/barron2005/).

\section{Results}

\subsection{Biogenic opal and calcium carbonate}

The biogenic opal records of GGC55/JPC56 and DSDP 480 from prior to about 6 ka display similar trends, with relatively high values during the BøllingAllerod followed by greatly reduced values during the $\mathrm{YD}$, and increased values characterizing the early and middle parts of the Holocene (Pride et al., 1999; Barron et al., 2004) (Fig. 3a). In general, percent biogenic opal is higher in the eastern Guaymas Basin sediments than it is in those of the western Guaymas Basin. A major opal spike centered on about $8.2 \mathrm{ka}$ is present in the eastern Guaymas Basin, but is absent in the western Guaymas Basin. Barron et al. (2004) suggested that this $\sim 8.2 \mathrm{ka}$ spike at DSDP 480 was associated with a shift in atmospheric circulation over North America (Dean et al., 2002) that resulted in an intensification of northwesterly winds over the northern Gulf during winter. However, it more likely that this $\sim 8.2 \mathrm{ka}$ spike reflects an increase in late winter/ early spring winds which drive upwelling on the mainland side of the Gulf.

At $\sim 5.6 \mathrm{ka}$, percent biogenic opal began a declining trend in GGC55/JPC56, falling from average values close to $40 \%$ to values that are generally $<25 \%$ by about $5 \mathrm{ka}$ (Pride et al., 1999). At DSDP 480 , on the other hand, a Holocene trend of increasing 
percent biogenic opal continued past $6 \mathrm{ka}$ into the later Holocene. Apparently, conditions favorable for diatom continued to be enhanced in the eastern Guaymas Basin after about $6 \mathrm{ka}$, while rapidly diminishing in the western Guaymas Basin (Pride et al., 1999; Barron et al., 2004).

In Fig. 3b, the weight percent calcium carbonate record of GGC55/JPC56, which reflects coccolith abundance, is compared with that of DSDP 480 (Barron et al., 2004). These calcium carbonate records are remarkably similar for the period prior to $11 \mathrm{Ma}$, with lower values during the BøllingAllerod and the earliest Holocene and increased values characterizing the YD and latest glacial (15.0 to $14.6 \mathrm{ka}$ ). Basically, the calcium carbonate records are the inverse of the biogenic opal records. Beginning at $11 \mathrm{ka}$, however, calcium carbonate disappeared from sediments of the eastern Guaymas Basin (DSDP 480), while it varied between absent and very low levels in the western Guaymas Basin (GGC55/JPC56). After about $6.2 \mathrm{ka}$, the percentage contribution of calcium carbonate increased in the GGC55/JPC56 record, but it remained virtually absent at DSDP 480 (Fig. 3b).

\subsection{Diatoms}

Records of four climatically-important diatom groups in GGC55/JPC56 between 0 and $1669 \mathrm{~cm}$ composite depth $(=\mathrm{cm} \mathrm{cd})$ (about 2.2 and $14.84 \mathrm{ka}$ ) are plotted vs. age in Figs. 4 and 5, where they are compared with Barron et al. (2004)'s results from DSDP 480.

Azpeitia nodulifera, a tropical diatom, was most common in both records (typically $>35 \%$ ) during the latest glacial (15.0-14.6 ka) and the YD (12.9-11.6 ka) (Fig. 4a). During the Bølling-Allerod (14.6 to $12.9 \mathrm{ka})$, A. nodulifera typically made up $23 \%$ or less of the diatom assemblage, whereas during the earliest Holocene, it comprised 10 to $20 \%$ of the diatom assemblage. After about $11.0 \mathrm{ka}, A$. nodulifera was virtually absent from both records until about 6.2 ka. After $6.2 \mathrm{ka}$, A. nodulifera returned to both the eastern and western Guaymas Basin, varying between $\sim 2 \%$ and $15 \%$, but up to $>20 \%$ between about 5.4 and $4.2 \mathrm{ka}$.

Roperia tesselata, a diatom typical of late winterearly spring blooms in the modern central Gulf, displays percentage trends in mostly opposite to those of A. nodulifera (Fig. 4). Roperia tesselata began to be an important member of central Gulf diatom assemblages at the end of the YD. Between $11.65 \mathrm{ka}$ and about $5.6 \mathrm{ka}$, the percentage values of $R$. tesselata varied in high amplitude cycles, roughly every 200-300 years, with high values reaching $67 \%$ and low values reaching $2 \%$ in GGC55/ JPC56. Similar cycles occurred at DSDP 480, with $R$. tesselata relatively more common than in GGC55/JPC56 (Fig. 4b). Barron et al. (2004) suggested that the cycles might be preservational, because valves of $R$. tesselata are more lightly silicified than those of other centric diatoms such as Coscinodiscus spp. After about $5.4 \mathrm{ka}, R$. tesselata typically made up $<5 \%$ of the GGC55/JPC56 assemblage, whereas its percentages occasionally exceeded $30 \%$ in the DSDP 480 record, in cycles similar to those of the earlier parts of the Holocene (Fig. 4b).

Shelf-dwelling Actinoptychus spp. (A. bipunctatus and $A$. senarius), diatoms that are transported down slope by summer storms and/or during periods of lower sea levels, fluctuated between ca. 10 and $70 \%$ throughout the studied interval at both sites (Fig. 5a). They were relatively common during the Bølling-Allerod and earliest Holocene (30-60\%) and relatively rare $(<20 \%)$ during the YD. An abrupt $20 \%$ drop in the average percent Actinoptychus spp. at about $10 \mathrm{ka}$ coincided with a sharp drop in sediment accumulation rate (Fig. 2), possibly reflecting decreasing down-slope transport due to rising sea level.

Cyclotella spp. (mainly C. littoralis), a coastal diatom indicative of low production in warm, stratified, and nutrient-limited waters of the summer and early fall, displays a percent trend somewhat opposite to that of Actinoptychus spp. (Fig. 5b). Prior to around $10 \mathrm{ka}$, Cyclotella spp. were generally $<10 \%$ of the diatom assemblage in both the eastern and western Guaymas Basin. At about $10 \mathrm{ka}$, percent Cyclotella sp. increased stepwise to between 10 and $20 \%$, roughly coincident with a decline in percent Actinoptychus spp. (Fig. 5a). A second stepwise increase followed at around $5.4 \mathrm{ka}$ when peak values of Cyclotella spp. rose to $25-40 \%$, likely reflecting increased presence of warm, nutrient-limited waters during the summer. 

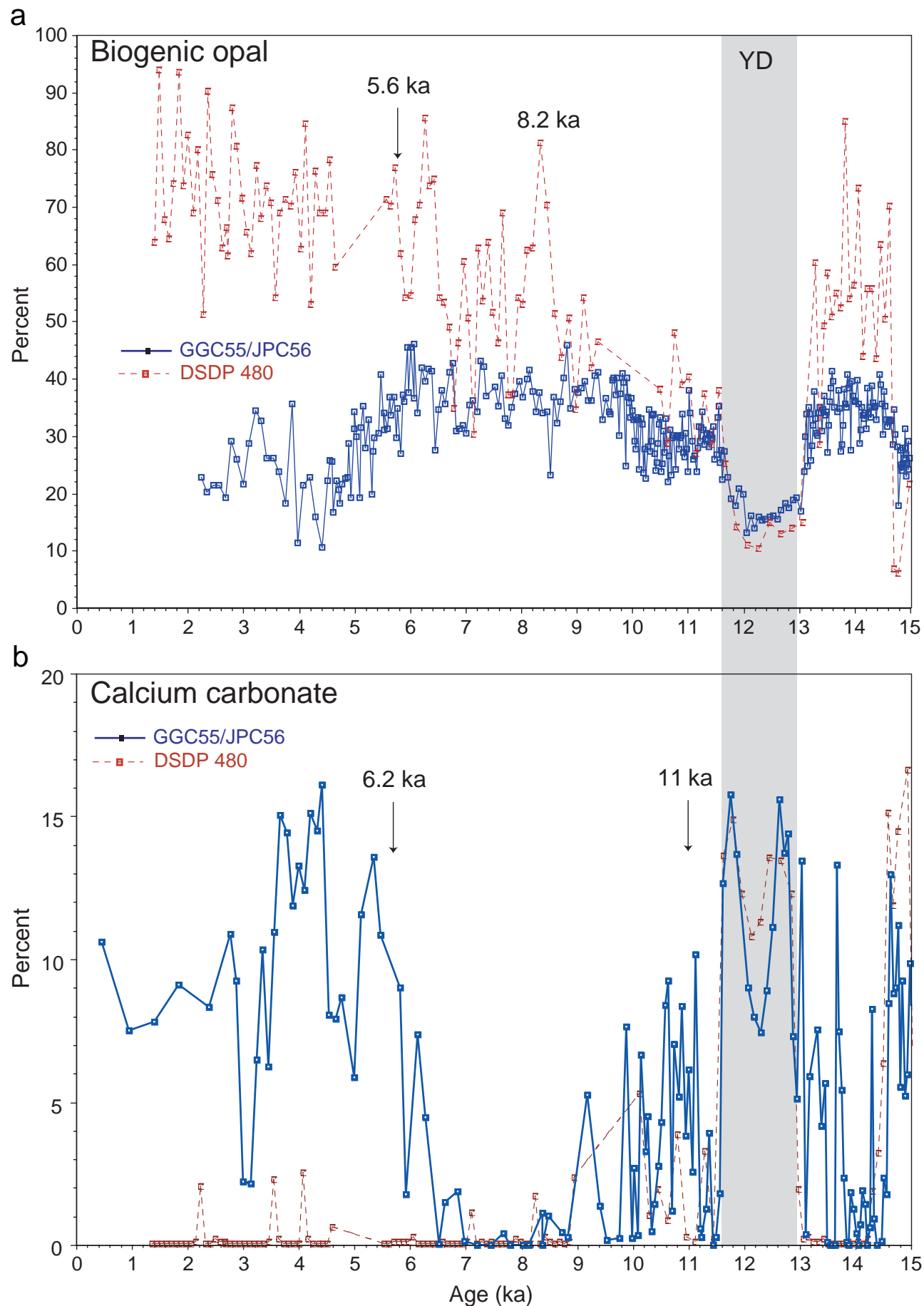

Fig. 3. Comparison of records of biogenic silica (a) and calcium carbonate (b) between GGC55/JPC56 (solid line) and DSDP 480 (dashed line). ka* refers to 1000 cal years B.P. 

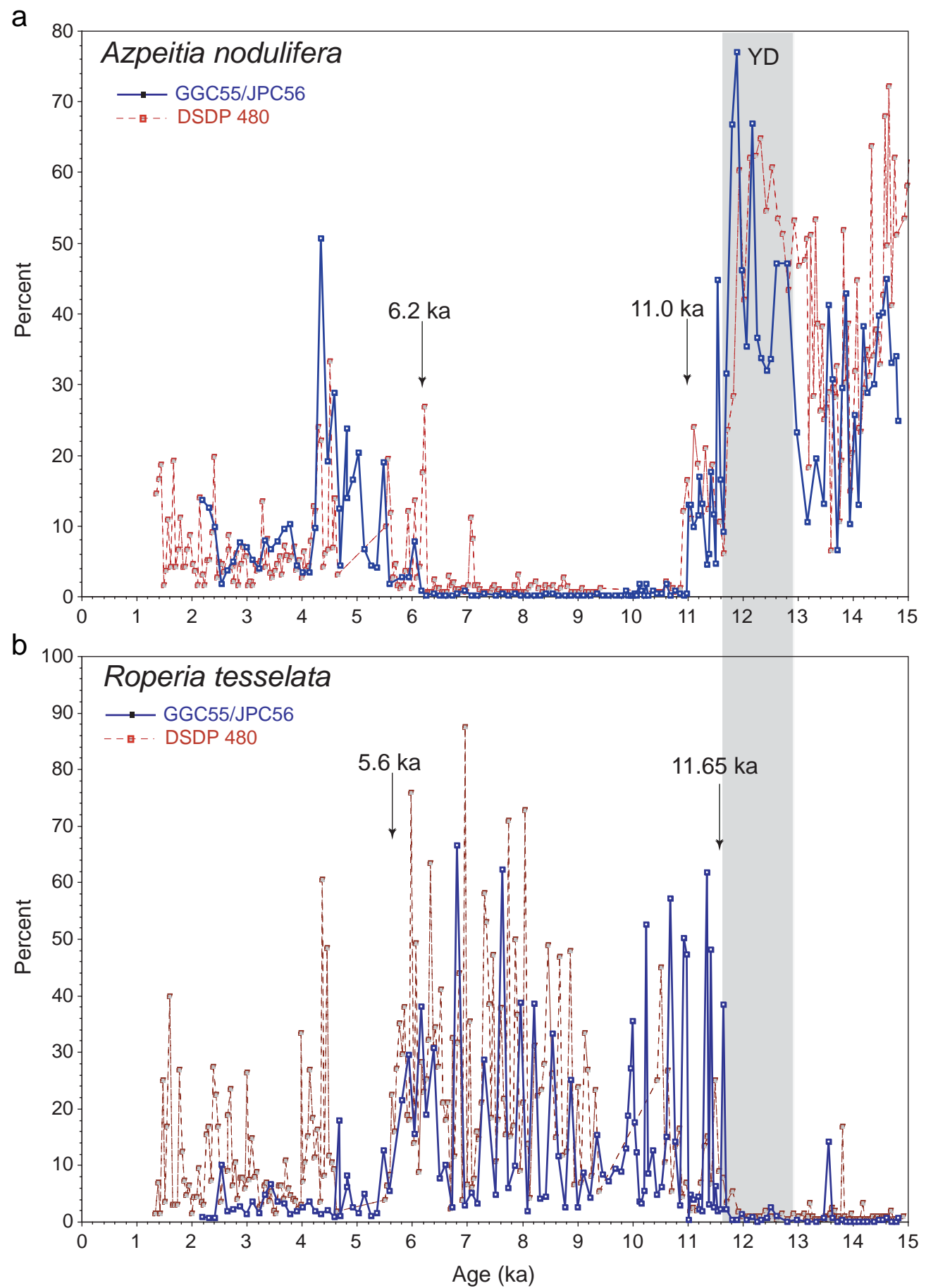

Fig. 4. Comparison of the percentages \# of the diatoms Azpeitia nodulifera (a) and Roperia tesselata (b) during the past 15,000 years at GGC55/ JPC56 (solid line) with DSDP 480 (dashed line). ka* refers to 1000 cal years B.P., \# percentages are of selected diatom taxa, see Materials and methods. 

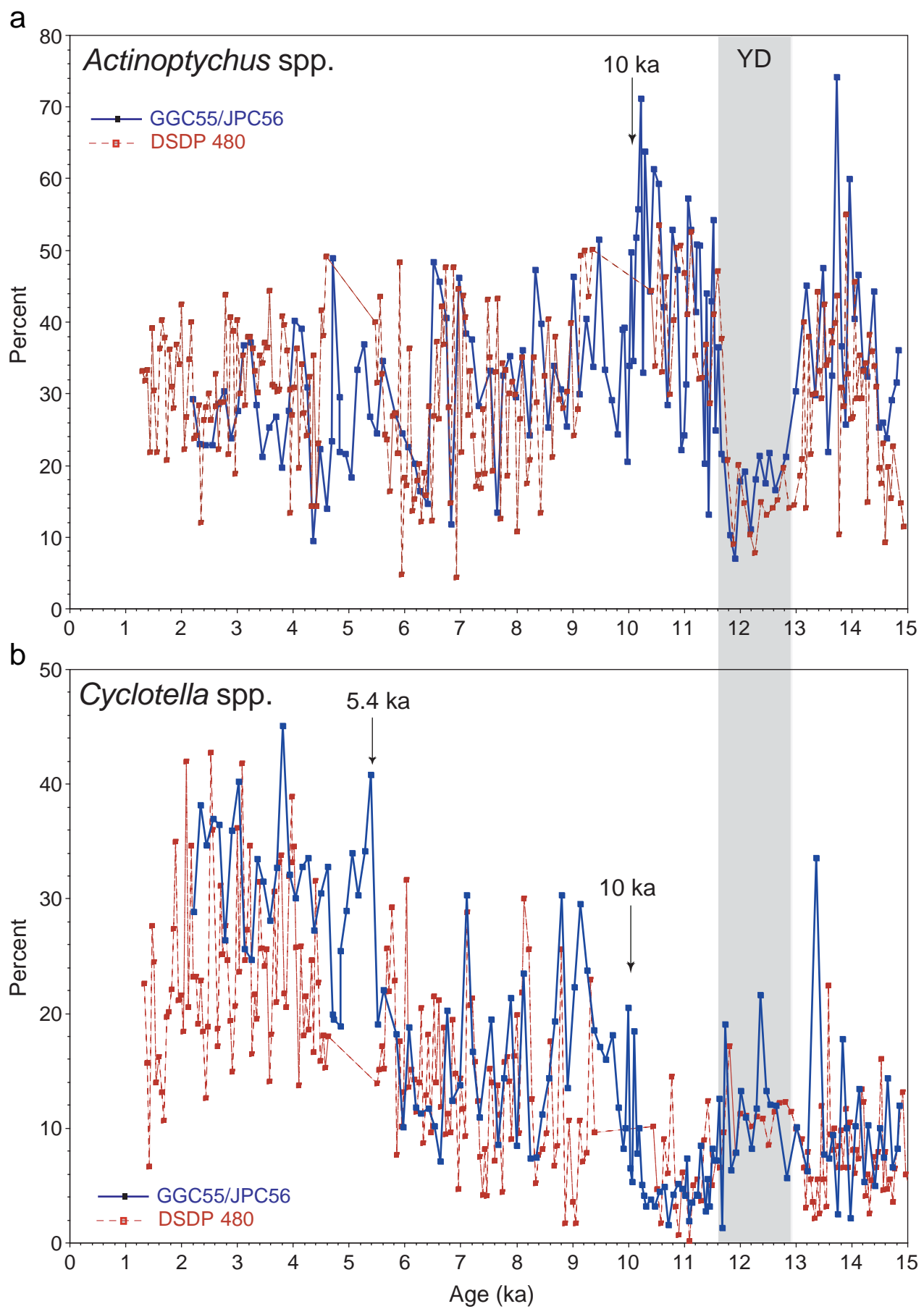

Fig. 5. Comparison of the percentages \# of the diatoms Actinoptychus spp. (a) and Cyclotella spp. (b) during the past 15,000 years at GGC55/ JPC56 (solid line) with DSDP 480 (dashed line). ka* refers to 1000 cal years B.P., \# percentages are of selected diatom taxa, see Materials and methods. 


\subsection{Silicoflagellates}

Diatoms overwhelmingly dominate the siliceous microfossils of cores GGC55/JPC56 and DSDP 480, but silicoflagellates are typically common to abundant, responding to most of the same physical and chemical environmental conditions as planktic diatoms. Percentages of selected silicoflagellate taxa in GGC55/JPC56 between 0 and $1669 \mathrm{~cm}$ composite depth $(=\mathrm{cm} \mathrm{cd})$ (about 2.2 and $14.84 \mathrm{ka}$ ) are plotted vs. age in Figs. 6 and 7, where they are compared with Barron et al.'s (2004) results from DSDP 480.

Octactis pulchra, a silicoflagellate associated with high primary productivity in the Gulf (Murray and Schrader, 1983), generally decreased upsection, but with considerable variability, from maximum values during the Bølling-Allerod (75-90\%) to lower values (15-30\%) by about $4 \mathrm{ka}$ in the GGC55/JPC56 record (solid line, Fig. 6a). The YD is marked by low percentages $(<40 \%)$, whereas the earliest Holocene $(11.6-10.4 \mathrm{ka})$ displays relatively high $(55-75 \%)$ values. During the middle part of the Holocene ( 10.4-5.4 ka), O. pulchra fluctuated between ca. 35 and $55 \%$ of the assemblage, before it decreased to minimal Holocene values (generally $>30 \%$ ) between about 5.4 and $3.4 \mathrm{ka}$. After $\sim 3.4 \mathrm{ka}$, O. pulchra increased to $>30 \%$, signaling a late Holocene increase in productivity.

The record of $O$. pulchra in the eastern Guaymas Basin (DSDP 480; Barron et al., 2004) is similar to that at GGC55/JPC56, especially prior to $\sim 10.4 \mathrm{ka}$. Between $\sim 10.4$ and $\sim 5.4 \mathrm{ka}$, however, O. pulchra was much more common in the western Guaymas Basin (GGC55/JPC56). This relationship appears to have been reversed after around $5.4 \mathrm{ka}$, with $O$. pulchra becoming slightly more common in the eastern than in the western basin.

In both the eastern and western Guaymas Basin, Dictyocha stapedia, a cosmopolitan silicoflagellate, displays overall trends that are generally opposite to those of O. pulchra (Fig. 6). Dictyocha stapedia increased from minimal values $(<20 \%)$ prior to about $11.4 \mathrm{ka}$ to peak values $(>40 \%)$ during the early part of the Holocene (about 10.4 to $8.4 \mathrm{ka}$ ). Thereafter, D. stapedia was moderately abundant (generally $>40 \%$ ) throughout the rest of both records, with values fluctuating in marked 1200 - to 1500 -yearlong cycles with highs of ca. $50 \%$ and lows of ca.
$20 \%$. Between about 9 and $5.4 \mathrm{ka}$, D. stapedia was generally more common in the eastern than in the western Guaymas Basin, reflecting a trend opposite to that of $O$. pulchra. After about $5.4 \mathrm{ka}$, the GGC55/ JP56 and DSDP 480 trends of D. stapedia were more similar, with values decreasing by nearly twofold between about 3.2 and $2.6 \mathrm{ka}$.

The tropical silicoflagellates of the genus Dictyocha, which includes $D$. calida, D. calida ampliata, and D. perlaevis, were similar at both sites (Fig. 7a), with peak values (generally 35-60\%) during the YD, similar to the record of the tropical diatom $A$. nodulifera (Fig. 4a). Low percentages of tropical Dictyocha $(>15 \%)$ characterize the Bølling-Allerod (14.6$12.9 \mathrm{ka})$ and the early and middle Holocene (11.6-5.5 $\mathrm{ka}$ ), but after $\sim 5.6 \mathrm{ka}$, they were more common. The similarity of the GGC55/JPC56 and DSDP 480 Holocene records of tropical diatoms and silicoflagellates (Figs. 4a, 7a) argues for lower SSTs in the central Gulf during the early to middle Holocene (11.6 to $5.5 \mathrm{ka}$ ) and higher SSTs after $\sim 5.4 \mathrm{ka}$.

Dictyocha sp. aff. D. aculeata, a Gulf variant of Dictyocha aculeata, is associated with the modern California Current. It is distinguished from D. aculeata s.s. by its larger size and by its canted apical bar and slightly bowed basal ring (see Appendix). Dictyocha sp. aff. D. aculeata increased abruptly to $>60 \%$ of the GGC55/JPC56 silicoflagellate assemblage during a very brief period near the end of the YD (about 11.73 to $11.53 \mathrm{ka}$ ), before rapidly declining to near absence for most of the Holocene (Fig. 7b; Plate I). A similar acme apparently started slightly earlier at DSDP 480, but the difference might be due to a lack of precision in the time scales for the YD (Fig. 7b). This distinctive YD silicoflagellate event has not been seen outside the Gulf. Minor increases of Dictyocha sp. aff. D. aculeata to 5 to $10 \%$ of the assemblages occurred between around 5.6 and $4.8 \mathrm{ka}$ in both records, and again between about 2.4 and $2.2 \mathrm{ka}$ (Plate II).

\section{Discussion}

\subsection{General remarks}

Biogenic and microfossil proxies generally display similar trends in the GGC55/JPC56 record from the 

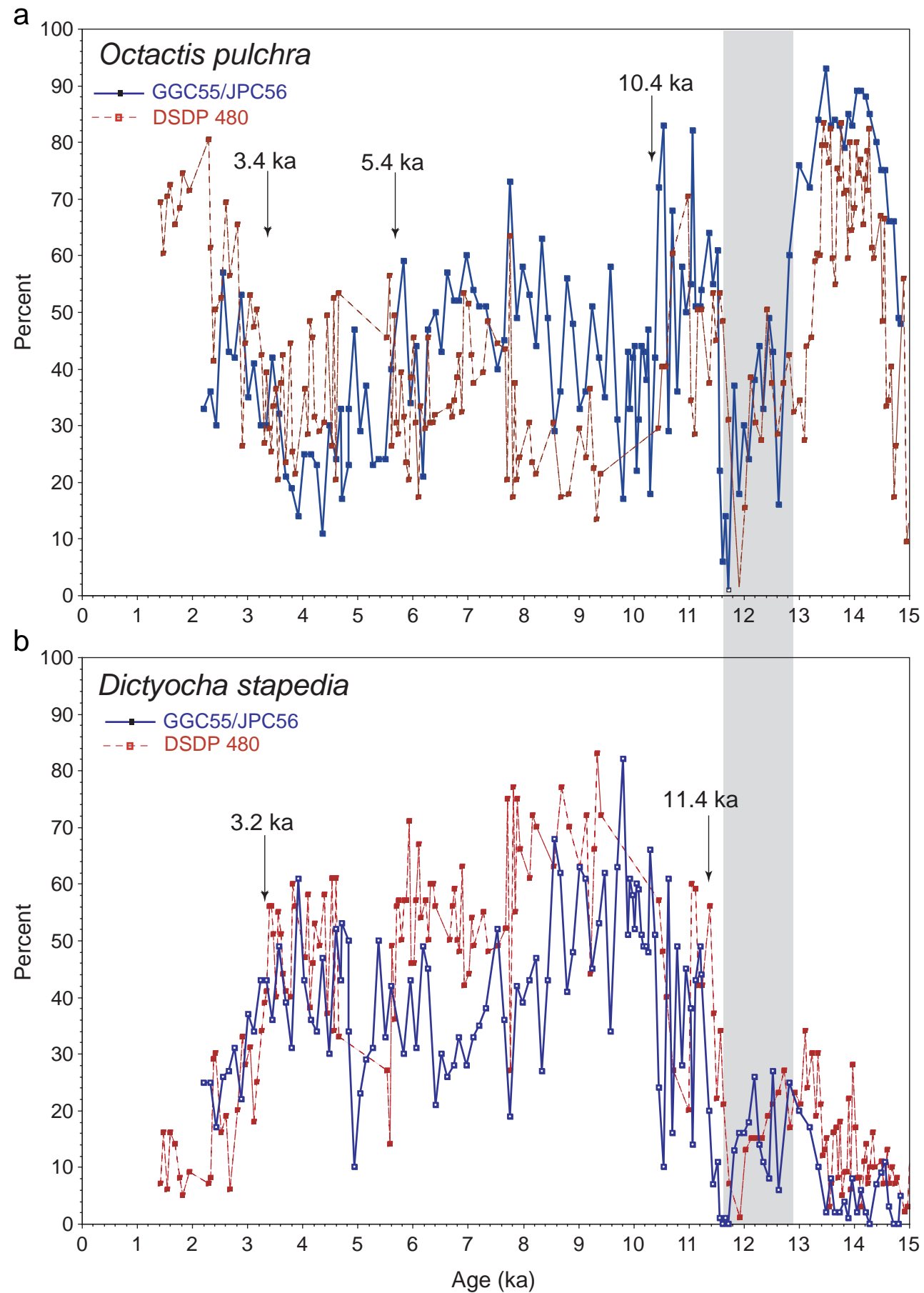

Fig. 6. Comparison of the relative contributions of the silicoflagellates Octactis pulchra (a) and Dictyocha stapedia (b) during the past 15,000 years at GGC55/JPC56 (solid line) with DSDP 480 (dashed line). ka* refers to 1000 cal years B.P. 

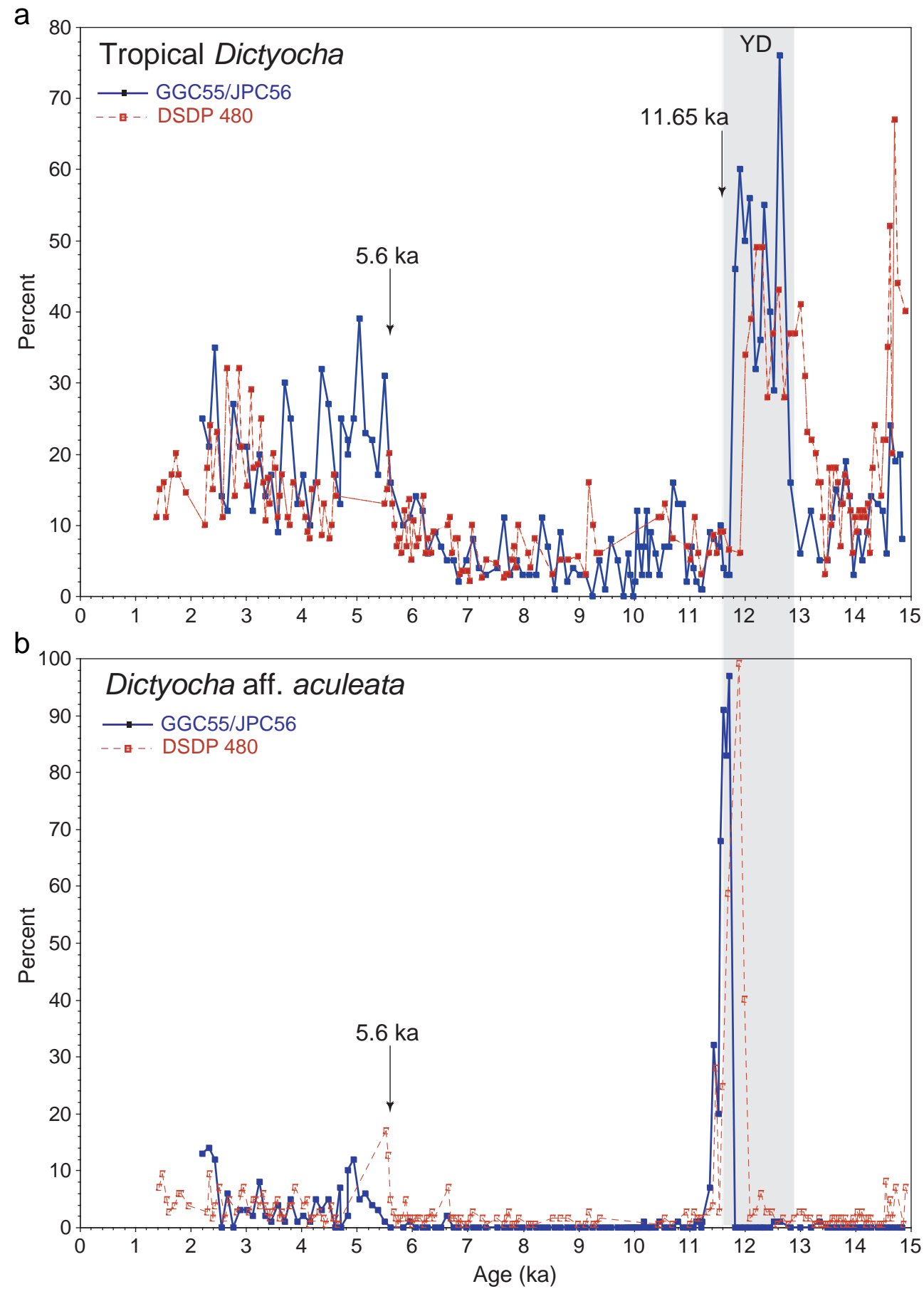

Fig. 7. Comparison of the relative contributions of the silicoflagellates tropical Dictyocha spp. (a) and Dictyocha sp. aff. D. aculeata (b) during the past 15,000 years at GGC55/JPC56 (solid line) with DSDP 480 (dashed line). ka* refers to 1000 cal years B.P. 
western Guaymas basin and in the DSDP480 record from the eastern Guaymas Basin during the past 15 kyr (Figs. 3-7). Basin-wide events coincided with the onset of the Bølling-Allerod and the onset and termination of the YD were abrupt and synchronous. Prior to about $6.2 \mathrm{ka}$, cross-basin differences were minimal in the central Gulf, although biosiliceous productivity was mostly higher in the eastern than it was in the western basin (Fig. 3a). After about 6 ka, east-west differences were enhanced, with biosiliceous productivity continuing to increase in the east but rapidly declining in the west (Figs. 3, 6). As percent biogenic opal decreased, weight percent calcium carbonate became a consistent component of western Guaymas Basin sediments.

\subsection{Bølling-Allerod (14.6-12.9 ka)}

During the Bølling-Allerod, marine conditions in the central Gulf were similar to those of today, with high winter biosiliceous productivity apparently induced by the turnover of surface waters caused by strong northwesterly winds (Sancetta, 1995; Pride et al., 1999). Silicoflagellate assemblages resembled those of the modern Gulf, with high relative abundance of $O$. puchra, the productivity indicator, and low relative abundance of tropical Dictyocha spp. Compared to the modern Gulf, Roperia tesselata and Cyclotella spp. were less common, whereas the tropical diatom $A$. nodulifera was more common in the Bølling-Allerod at both sites. This suggests that the influence of tropical waters in the Guaymas Basin was seasonally stronger during the Bølling-Allerod than at present. It is also likely that the strength of the winter northwesterly winds was considerably less during the Bølling-Allerod than at present, probably due to changing solar isolation (Berger, 1978; Bartlein et al., 1998). Van Devender et al. (1990) argue that prior to around $10 \mathrm{ka}$, winter rainfall in northwest Mexico was considerably higher than at present, lending further support to the theory that atmospheric conditions differed from those of the present.

\subsection{Younger Dryas (12.9-11.6 ka)}

The YD at both sites is marked by reduced percent biogenic opal (Fig. 3a; Pride et al., 1999) and reduced percentages of diatoms and silicoflagellates associated with high biosiliceous productivity ( $R$. tesselata, $O$. pulchra; Figs. 4b, 6a). A reduction in winter-tospring northwest winds and/or a reduction in the nutrient content of the upwelled waters must have occurred (Sancetta, 1995; Pride et al., 1999). Increased calcium carbonate percentage (Fig. 3b) and increases in the abundance of the tropical diatom A. nodulifera (Fig. 4a) and tropical silicoflagellate Dictyocha spp. (Fig. 7a) suggest that tropical conditions extended throughout the year in the central Gulf, with no true winter-to-spring upwelling season. This contrasts with widespread evidence that the YD was characterized by cooler SSTs in the middle latitude eastern Pacific (Kennett and Ingram, 1995; Barron et al., 2003b).

Ganeshram and Pedersen (1998) argue that reduced primary productivity off northwest Mexico during glacial intervals was due in part to reduced land-ocean thermal contrast and reduced wind-induced upwelling. Pride et al. (1999) suggest that similar processes may have characterized the YD in the Gulf, along with a possible inflow of younger, nutrient-poor subsurface waters. In support of the latter hypothesis, Pride et al. (1999) point out that reduced $\delta{ }^{15} \mathrm{~N}_{\text {org }}$ and bioturbated sediments during the YD are indicative of enhanced ventilation of intermediate waters. Thus, both reduced productivity and reduced ventilation of subsurface waters are suggested for the YD.

Koutavas et al. (2002) argue that persistent El Niño-like conditions were present in the cold tongue of the eastern equatorial Pacific during the last glacial interval and the YD, based on their study of $\mathrm{Mg}$ / $\mathrm{Ca}$ ratios of the planktic foraminifer Globigerinoides sacculifer in piston core V21-30 near the Galapagos Islands. They show that warming of eastern equatorial Pacific cold tongue SSTs during the last glacial and YD contrasts with cooling of SSTs in proxy records from the South China Sea area of the western equatorial Pacific, implying a reduced east-west thermal gradient similar to that which occurs during El Niños. Stott et al. (2002) also argue for widespread El Niño-like conditions in the equatorial Pacific during stadials (glacials) of the past $70 \mathrm{kyr}$ based on their studies of the $\delta^{18} \mathrm{O}$ and $\mathrm{Mg} / \mathrm{Ca}$ records of planktonic foraminifers in the western equatorial Pacific. 
Increases in the relative contributions of tropical diatoms and silicoflagellates during the YD in the central Gulf agree with Koutavas et al.'s (2002) and Stott et al.'s (2002) arguments for widespread El Niño-like conditions in the tropical Pacific, and with Keigwin (2002)'s $\delta^{18} \mathrm{O}$ data for the planktic foraminifers Neogloboquadrina pachyderma and Globigerina bulloides, which do not reveal YD cooling in JPC56.

The end of the YD was marked by the return of high biosiliceous productivity in the central Gulf, with a doubling of values of weight percent biogenic opal in JPC56 during the later part of the YD from lows of ca. $15 \%$ prior to about $11.9 \mathrm{ka}(1045 \mathrm{~cm} \mathrm{~cd})$ to values of ca. $30 \%$ by $11.57 \mathrm{ka}(1100 \mathrm{~cm} \mathrm{~cd}$; Fig. $3 \mathrm{a}$; Pride et al., 1999). A decline in the percent $A$. nodulifera and a rise in $R$. tesselata began at about 11.9 ka (Fig. 4b), suggesting that biosiliceous productivity began to increase in the central Gulf prior to the end of the YD. During this same period, the tropical silicoflagellates Dictyocha spp. declined abruptly, whereas $D$. sp. aff. aculeata became the dominant silicoflagellate in the central Gulf (Fig. 7b). Based on the association of $D$. sp. aff. aculeata with periods of warmer SSTs during the past 2000 years in core BAM80-E17 from the eastern Guaymas Basin (Barron et al., 2003a), the brief dominance of this species may represent a distinctly warm event in the central Gulf; but there is as yet no evidence from other proxies. Alternatively, the rapid increase of $D$. sp. aff. aculeata in the central Gulf at $\sim 11.9$ ka may signal an influx of California Current water. Whatever the significance of the late YD acme of $D$. sp. aff. D. aculeata, it is clear that paleoceanographic conditions began to change in the central Gulf, well before the end of the YD (11.65 ka).

\subsection{Earliest Holocene (11.65-11.0 ka)}

The end of the YD was marked by an abrupt reduction in weight percent calcium carbonate and a $>10 \%$ increase at both locations (Fig. 3b). Laminated sediments abruptly returned in cores (Keigwin and Jones, 1990; Sancetta, 1995; Pride et al., 1999), evidence of expansion of the oxygen minimum zone. Between about 11.65 and $11.55 \mathrm{ka}, O$. pulchra, a silicoflagellate indicative of high biogenic productivity, increased significantly to $50-60 \%$ of the silicoflagellate assemblage (Fig. 6a), suggesting the return of conditions similar to those of the Bølling-Allerod.

\subsection{Cool conditions in the central Gulf ( $\sim 11$ to $\sim 6.2 \mathrm{ka}$ )}

Between about 11.0 and $6.2 \mathrm{ka}$, the tropical diatom $A$. nodulifera was virtually absent from both records, while $R$. tesselata increased (Fig. 4b). Schrader et al. (1986) report that $R$. tesselata is dominant in phytoplankton in the cooler waters (SST's $<20{ }^{\circ} \mathrm{C}$ ) of the northern Gulf (north of $\left.28^{\circ} 30^{\prime} \mathrm{N}\right)$. Sancetta (1995) and Barron et al. (2004) argued that between about 11.0 and $6.2 \mathrm{ka}$, tropical waters were virtually excluded from the central Gulf, probably as a result of intensification in the strength and/or duration of northwest winter winds. Most of this $\sim 11.0$ to $6.2 \mathrm{ka}$ interval was characterized by absence or very low levels of calcium carbonate microfossils (foraminifers and coccoliths; Fig. 3b; K. McDougall, written communication, 2004), lending support to these arguments. Similarly, the relative abundance of tropical silicoflagellates was greatly reduced in both records during this $\sim 11.0$ to $6.2 \mathrm{ka}$ interval (Fig. 7a), whereas D. stapedia, a cosmopolitan silicoflagellate, became dominant in the central Gulf (Fig. 6b).

\subsection{Return of tropical elements and the onset of the monsoon (6.2 to $5.6 \mathrm{ka})$}

Beginning at around $6.2 \mathrm{ka}$, the return of the tropical diatom Azpeitia nodulifera to both Guaymas Basin records is evidence of the return of seasonal incursions of tropical waters into the central Gulf (Fig. 4a). At about $5.6 \mathrm{ka}$, tropical Dictyocha spp. increased to $>15 \%$ of the silicoflagellate assemblage, while $A$. nodulifera increased briefly to ca. $20 \%$ of the diatom assemblage in both records (Figs. 4a, 7a), suggesting a major warming of central Gulf surface waters. A stepwise increase of Cyclotella spp. to $25-40 \%$ of the GGC55/JPC56 assemblage at about 5.4 ka (Fig. 5b) is further evidence of significant warming of surface waters of the central Gulf. Keigwin (2002) observed a decrease in $\delta^{18} \mathrm{O}$ in $N$. pachyderma in JPC56 between about 6 and 5 ka that may also indicate warming of the surface waters of the central Gulf. 
Accompanying this $\sim 6.2$ to $5.4 \mathrm{ka}$ warming of surface waters, low levels of coccoliths returned to GGC55/JPC56, but not to DSDP 480 (Fig. 3b). Modern patterns of increased calcium carbonate in sediments from the western Guaymas Basin compared to that of the eastern Guaymas Basin (Baba et al., 1991) were apparently established during this $\sim 6.2$ to $5.4 \mathrm{ka}$ interval.

Mitchell et al. (2002) demonstrated a strong relationship between SSTs in the northern Gulf and the presence of monsoonal rainfall in Arizona and New Mexico, arguing that monsoonal rainfall cannot travel up the length of the Gulf until northern Gulf SSTs exceed $26{ }^{\circ} \mathrm{C}$. Diatom, silicoflagellate, and biogenic sediment proxies from GGC55/JPC56 and DSDP 480 suggest that prior to $\sim 6.2 \mathrm{ka}$, SSTs could not have been warm enough in the northern Gulf to allow the development of summer monsoonal conditions in Arizona and New Mexico.

Evidence for the American Southwest is supportive of a post- $6 \mathrm{ka}$ onset of the modern monsoon. Pack rat midden records from the Sonoran Desert (Spaulding, 1991) strongly suggest that between 7.5 and $4.7 \mathrm{ka}$, it was drier than present. Ely et al. (1993) argues that floods in Arizona and southern Utah were numerous between 4800 and 3600 radiocarbon years ago (this converts to $\sim 5.6$ to $\sim 3.9 \mathrm{ka}$ according to the calibration equations of Stuiver et al., 1998). Similarly, Waters and Haynes (2002) report that the frequency of arroyo cutting and filling in the American Southwest increased dramatically after 4000 radiocarbon years ago ( $\sim 4.5 \mathrm{ka}$ calendar according to Stuiver et al., 1998), implying that that the frequency and severity of summer monsoonal thunderstorms increased at that time. Based on a study of a 4000-year annually resolved climate history from columnar stalagmites in caves of the Guadalupe Mountains of southeast New Mexico, Polyak and Asmerom (2001) argue that the climate between 4 and $3 \mathrm{ka}$ resembled that of the present day after a drier middle Holocene. Kristin McDougall (written communication, 2004) suggests that an increase of transported shallow water benthic foraminifers in JPC56 after about $5.2 \mathrm{ka}$ implies an increase in runoff and sediment input from the land, after a widespread drought during the middle part of the Holocene.

\subsection{Shift in late winter-early spring wind direction} ( 6.0 to $5.4 \mathrm{ka})$

Prior to about $6 \mathrm{ka}$, the biogenic opal records of GGC55/JPC56 and DSDP 480 displayed parallel trends, with values of percent biogenic opal typically higher in the eastern than in the western Guaymas Basin (Fig. 3a). After about $5.6 \mathrm{ka}$, percent biogenic opal began a steady decline in the west (Pride et al., 1999), whereas it continued to increase in the east. Also at $\sim 6.2 \mathrm{ka}$, calcium carbonate began increasing in sediments of the west, whereas it remained virtually absent from those of the east. Beginning at around $5.4 \mathrm{ka}$, the productivity-related silicoflagellate, O. pulchra, first became more common in the GGC55/JPC56 record than in the DSDP 480 record (Fig. 6a). After about $5.4 \mathrm{ka}$, the diatom Roperia tesselata decreased (to typically $<5 \%$ ) in the west but remained relatively common in the east (Fig. 4b). Together, these proxies suggest that modern-day east-west contrasts in the Guaymas Basin commenced between about 6.2 and $5.4 \mathrm{ka}$, possibly because late winter-early spring coastal upwelling was enhanced on the eastern (mainland) side of the Guaymas Basin, leading to increased biosiliceous productivity there. At the same time, upwelling conditions favorable to biosiliceous productivity began to decline on the western side of the Guaymas Basin.

According to Bandon-Dangon et al. (1991), the coastal upwelling on the mainland side of the central Gulf during the late winter-early spring results from local winds that have a strong offshore component. Late winter-early spring winds on the western side of the central Gulf, on the other hand, are more parallel to the coast and are less conducive to upwelling. We propose that a major shift in late winter-early spring wind direction occurred over the central Gulf between about 6.2 and $5.4 \mathrm{ka}$, resulting in enhanced coastal upwelling on the eastern side and reduced diatom productivity on the western side. In support of this argument, a high-resolution regional climate model by Diffenbaugh and Sloan (2004) shows that sometime after $6 \mathrm{ka}$, surface wind vectors over the northern Gulf during February became more southeasterly, thus more favorable to coastal upwelling; whereas during earlier parts of the Holocene, late winter-early spring wind vectors were more southerly. Sancetta (1995) came to a similar conclusion, as she speculated that 
"at some point in the middle Holocene," "there was a rapid shift to present conditions, with northwesterly winds persisting into spring, resulting in a more even balance of winter and spring production."

Widespread paleoceanographic changes in adjacent low latitude regions at about the same time may be related to this proposed wind shift. Haug et al. (2001) recorded an abrupt shift to drier conditions in the Cariaco Basin off Venezuela at $\sim 5.4 \mathrm{ka}$ and argued that this was caused by a southward shift in the mean position of the ITCZ occurred in the Caribbean in response to increasing El Niño-like conditions in the eastern equatorial Pacific. Proxy sediment data from Peru (Sandweiss et al., 2001) and Ecuador (Moy et al., 2002), SST data from the Galapagos (Koutavas et al., 2002), and modeling studies (Clement et al., 2000) all suggest that ENSO variability increased at around $5 \mathrm{ka}$ after being suppressed during the middle part of the Holocene.

\subsection{Enhanced productivity at $\sim 2.8 \mathrm{ka}$}

Increased numbers of $O$. pulchra after $2.8 \mathrm{ka}$ at DSDP 480 are evidence for enhanced spring upwelling (Barron et al., 2004). A similar increase is evident in the GGC55/JPC 56 record (Fig. 6a), where it also coincides with a stepwise decrease of D. stapedia. Barron et al. (2004) suggested that increased amplitude in the percentage variations of biogenic silica and weight percent $\mathrm{Fe}, \mathrm{Al}$, and $\mathrm{Ti}$ (proxies of terrigenous input) in the DSDP 480 records after about $2.8 \mathrm{ka}$ reflected the intensification of ENSO cycles and the establishment of modern oceanographic conditions in the Gulf. The biogenic sediment, diatom, and silicoflagellate proxies of GGC55/JPC56, however, do not reveal increased amplitude variations after about 2.8 $\mathrm{ka}$, either because the sampling interval is too coarse or because the western Guaymas Basin is not as sensitive to ENSO-driven oceanographic change as the eastern Guaymas Basin.

\section{Conclusions}

Although our biogenic proxies display mostly similar trends in the western and eastern Guaymas Basin during the past 15,000 years, important differences are also apparent between sites that lie only $\sim 65 \mathrm{~km}$ apart.
- The biogenic opal records of GGC55/JPC56 (Pride et al., 1999) and DSDP 480 were remarkably similar throughout the past 15,000 years; however, beginning at $\sim 5.4 \mathrm{ka}$, western Guaymas Basin sediments experienced a permanent ca. $20 \%$ drop in biogenic opal, whereas eastern Guaymas Basin sediments became increasingly richer in biogenic opal.

- Prior to $\sim 6 \mathrm{ka}$, the calcium carbonate records at both sites were remarkably similar; but east-west differences were enhanced during the late Holocene.

- The tropical diatom Azpeitia nodulifera and tropical silicoflagellates of the genus Dictyocha display relative abundance trends in both records that are similar to those of calcium carbonate, with increased values during the YD and after $\sim 5.6 \mathrm{ka}$.

- The scarcity of tropical diatoms and silicoflagellates in both central Gulf records between $\sim 11 \mathrm{ka}$ and $\sim 6 \mathrm{ka}$ argue against the presence of presentday monsoonal conditions in the American Southwest during much of the early and middle parts of the Holocene.

- A $\sim 5.4 \mathrm{ka}$ shift in the mean wind direction over the northern Gulf during the late winter to early spring from a previously more southerly direction to a more southeasterly direction, more favorable to coastal upwelling may have been responsible for changes these late Holocene changes. Increasing ENSO-like conditions in the eastern tropical Pacific probably had a major affect on low latitude atmospheric circulation in the region.

\section{Acknowledgements}

We are grateful to Constance Sancetta for sending us her diatom data and to Kris McDougall for sending us a copy of her manuscript on the benthic foraminifers of JPC56. We also appreciate discussions and the exchange of data with Lloyd Keigwin and Robert Douglas. Thanks are due to Lloyd Keigwin for providing samples of GGC55 and JPC56. Kris McDougall and Scott Starratt of the USGS provided very helpful reviews of the preliminary manuscript. We are grateful to suggestions offered by Lloyd Burckle and Carol Pride in their formal reviews of our paper and to the careful editing and suggestions made by Ellen Thomas, the journal editor. 


\section{Appendix A. Appendix}

Taxonomic reference list:

Diatoms:

Actinocyclus curvatulus Janisch, 1878

Actinocyclus octonarius Ehrenberg, 1838

Actinoptychus bipunctatus Lohman, 1941

Actinoptychus senarius (Ehrenberg) Ehrenberg, 1843

Azpeitia nodulifera (A. Schmidt) G. Fryxell and PA Sims, 1986

Coscinodiscus asteromphalus Ehrenberg, 1844

Coscinodiscus grannii Gough, 1905

Coscinodiscus radiatus Ehrenberg, 1839

Coscinodiscus oculusiridis Ehrenberg, 1841

Cyclotella littoralis Lange and Syvertsen, 1989

Roperia tesselata (Roper) Grunow ex Pelletan, 1889

Stephanopyxis palmeriana (Greville) Grunow, 1884

Silicoflagellates:

Dictyocha aculeata (Lemmermann) Dumitrica, 1973

Dictyocha calida calida Poelchau, 1976

Dictyocha calida ampliata Bukry, 1979

Dictyocha perlaevis Frenguelli, 1951

Dictyocha stapedia Haeckel, 1887

Dictyocha subaculeata (Bukry) Bukry, 1982

Octactis pulchra Schiller, 1925

Dictyocha sp. aff. D. aculeata (Lemmermann) Dumitrica

\section{A.1. Introduction}

A large, robust silicoflagellate tabulated as Dictyocha sp. aff. D. aculeata dominates floras at DSDP 480 and JPC56 for a brief interval at the end of the Younger Dryas (YD). The consistent large size (maximum length $60-70 \mu \mathrm{m}$, ring $40-50 \mu \mathrm{m}$ ) and polymorphic character punctuates the normal succession of the smaller, more typical species in the Gulf.
Although a few of the specimens resemble oceanic Dictyocha aculeata by the cant of the apical bar and eight basal ring apices, the typical distinct basal pikes and linear surface texture of $D$. aculeata are missing.

The Gulf specimens of $D$. sp. aff. D. aculeata resemble some specimens illustrated as $D$. sp. aff. D. aculeata from tropical Pacific site DSDP 425 (Bukry, 1980, p. 552, Plate I, Figs. 5-7). The compared specimens at DSDP 425 have large exposed basal ring pikes like $D$. aculeata, a feature missing on the Gulf forms.

In a study of modern plankton and surface sediment of the Gulf and nearby Pacific Ocean, Murray and Schrader (1983) noted that Pacific Dictyocha messanensis $[=D$. stapedia $]$ were dominated by small forms “....whereas, a larger form of D. messanensis (their Plate I, Fig. 19) was more prevalent in Gulf stations." Gulf waters may favor larger size in some taxa, such as D. sp. aff. D. aculeata.

\section{A.2. Description}

Dictyocha sp. aff. D. aculeata has a medium to long bar that may be plain or spired. The bar is only slightly canted from the major axis. Large horns may ornament the struts or strut-ring junction. Major axes spines are medium to long. The ring is rhombic, rounded or multiangled, similar to $D$. aculeata. Basal pikes are missing or small, abapically-directed knobs that are not evident in distal view. Strut junctions are offset from the ring axes. Surface texture is dominantly smooth on distal and proximal surfaces.

Plate I. Silicoflagellates from the Gulf of California and northwestern Pacific Ocean. Scale bar equals $10 \mu \mathrm{m}$ (see page 99).

$(1,2 ; 5,6) \quad$ Dictyocha sp. aff. D. aculeata (Lemmermann) Dumitrica. (1, 2) DSDP 480-3H-1, 105-106 cm; SEM, distal views; (5) JPC56, $902 \mathrm{~cm}$; LM, 50X objective, no visible basal pikes; (6) DSDP 480-3H-1, 100-101 cm; LM, 50× objective, canted bar.

(3, 4) Dictyocha aculeata (Lemmermann) Dumitrica. (3) ODP 1208A-4H-3, 75-76 cm, SEM, distal, linear texture, basal pikes; (4) BAM80 E17, 5-6 cm; LM, 50æ objective, full set of basal pikes, bar canted.

Plate II. Dictyocha sp. aff. D. aculeata (Lemmermann) Dumitrica. Scale bar equals $10 \mu \mathrm{m}$ (see page 100).

$(1,2) \quad$ Sample DSDP 480-3H-1, 105-106 cm; SEM. (1) Distal view, smooth texture, plain pointed spines; (2) proximal, small basal pikes, strut-horn extensions.

(35) Sample JPC56, $902 \mathrm{~cm}$; LM. (3) Apical focus of strut-horns; (4) ring focus, strut-horns and small basal pikes; (5) group with rhombic and partly angular rings. 


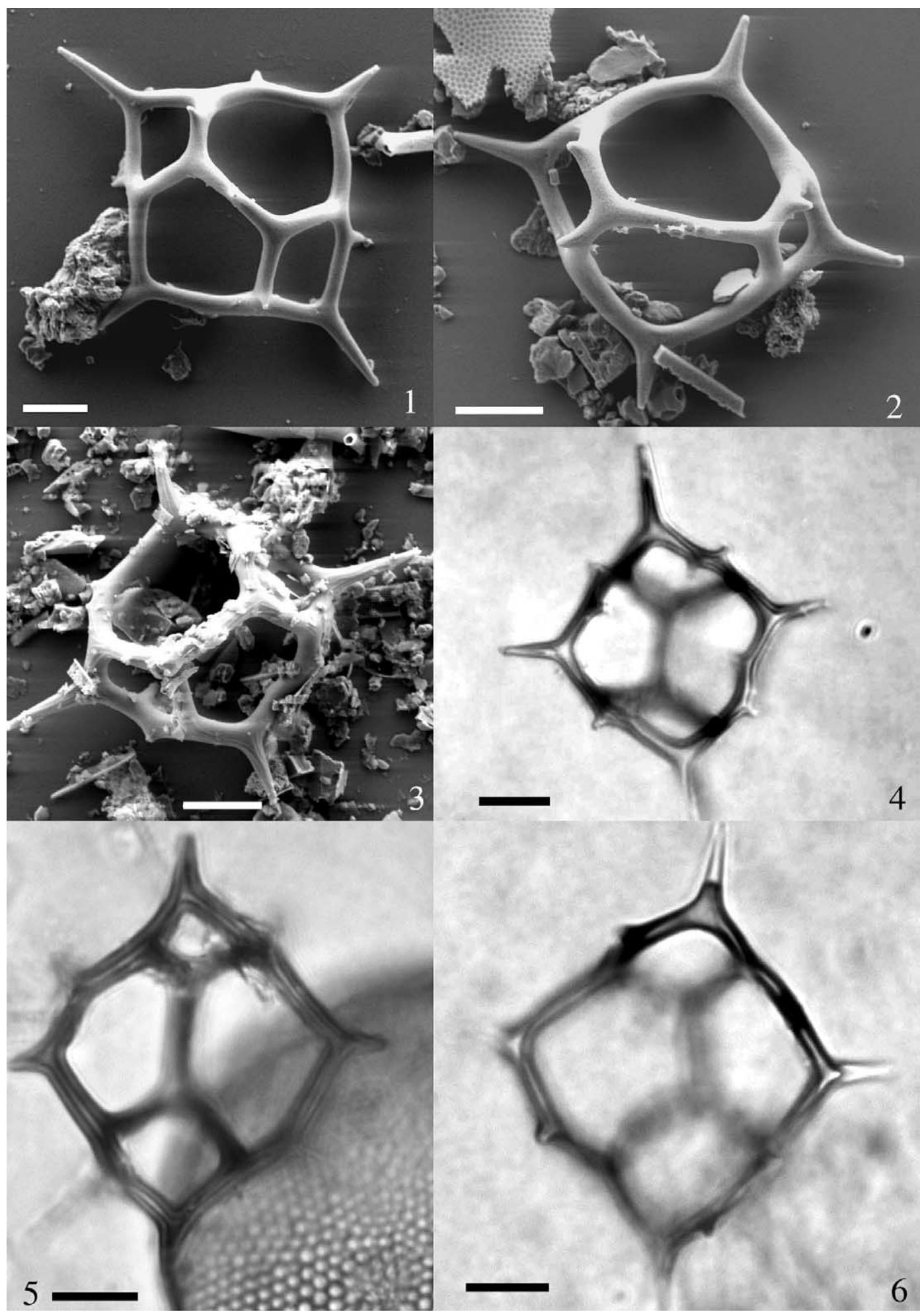

Plate I (caption on page 98). 


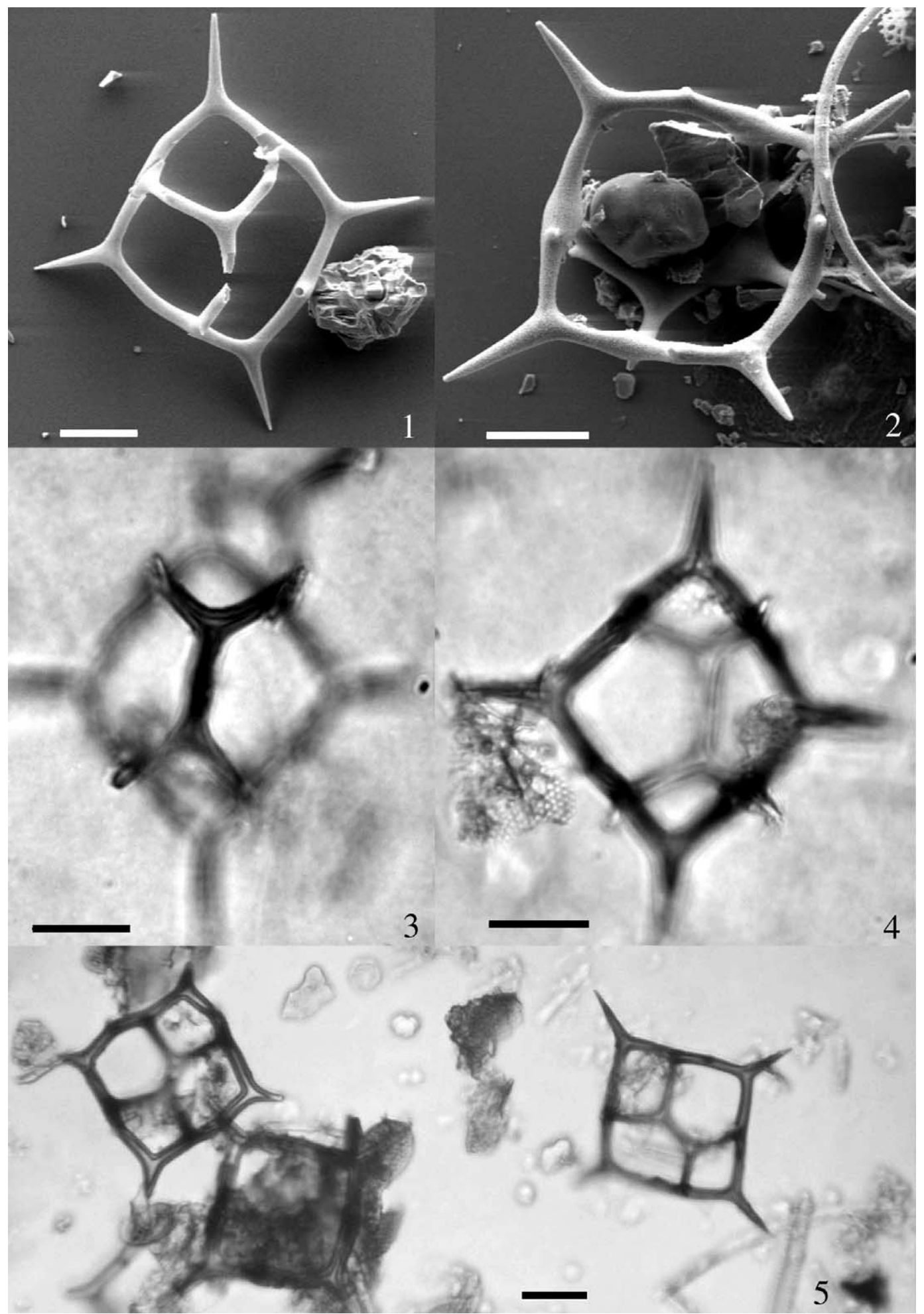

Plate II (caption on page 98). 


\section{A.3. Remarks}

The smooth texture, basal pike orientation and large size distinguish $D$. sp. aff. D. aculeata from D. aculeata. Large size and distinct basal pikes separate it from Dictyocha subaculeata. The polymorphic variation on the basal ring and bar and horn ornamentation in single specimens is wider than in most typological species.

\section{A.4. Gulf occurrences}

Dictyocha aculeata s.1. is rare (0-4\%) and very sporadic in Gulf Holocene sediment. The occurrences may represent brief oceanic floral incursions, without long term resident populations, because long cored intervals lack the species.

Dictyocha sp. aff. D. aculeata has a major acme interval around $11.6 \pm 0.3 \mathrm{ka}$ at the end of the YD that is recorded for both DSDP 480 in the eastern Guaymas Basin, and JPC56 in the western Guaymas Basin. Similarity in abundance, size, morphology, texture and ornamentation of the silicoflagellate skeletons shows a major single population event. Comparatively, the population at DSDP 480 has more canted bars and horn ornamentation. The JPC56 population has more straight-sided rings, fewer canted bars and more asperoid variants. Following this acme, $D$. sp. aff. $D$. aculeata persists as a low-frequency minor species, occasionally identified by large size and strut horn ornamentation, as at GGC55, $150 \mathrm{~cm}$.

\section{References}

Baba, J., Peterson, C.D., Schrader, H.J., 1991. Modern fine-grained sediments in the Gulf of California. In: Dauphin, J.P, Simoneit, B.R.T. (Eds.), The Gulf and Peninsular Province of the Californias, Am. Assoc. Petrol. Geol. Mem., vol. 47, pp. 569-587.

Bandon-Dangon, A., Dorman, C.E., Merrifield, M.A., Wianat, C.D., 1991. The lower atmosphere over the Gulf of California. J. Geophys. Res. 96 (C9), 16,877-16,896.

Barron, J.A., Bukry, D., Bischoff, J.L., 2003a. A 2000-yr-long record of climate from the Gulf of California. In: West, G. James, Blomquist, Nikki L. (Eds.), Proceedings of the Nineteenth Pacific Climate Workshop, Asilomar, Pacific Grove, CA, March 3-6, 2002, Technical Report 71 of the Interagency Ecological Program for the San Francisco Estuary, $11-21$.

Barron, J.A., Heusser, L., Herbert, T., Lyle, M., 2003b. High resolution climatic evolution of coastal northern California during the past 16,000 years. Paleoceanography 18 (1). doi:10.1029/ 2002 PA000768.

Barron, J.A., Bukry, D., Bischoff, J.L., 2004. High resolution paleoceanography of the Guaymas Basin, Gulf of California, during the past 15,000 years. Mar. Micropaleontol. 50 (3-4), 185-207.

Bartlein, P.J., Anderson, K.H., Anderson, P.M., Edwards, M.E., Mock, C.J., Thompson, R.S., Webb III, R.S., Whitlock, C., 1998. Paleoclimate simulations for North America over the past 21,000 years: features of the simulated climate and comparisons with paleoenvironmental data. Quat. Sci. Rev. 17 (6-7), 549-585.

Berger, A., 1978. Long-term variations of daily insolation and Quaternary climatic changes. J. Atmos. Sci. 35 (12), 2362-2367.

Bukry, D., 1980. Silicoflagellate biostratigraphy and paleoecology in the eastern Pacific Ocean, Deep Sea Drilling Project Leg 54. In: Rosendahl, B.R., Hekinian, R. (Eds.), Init. Repts, DSDP, vol. 54 , pp. 545-573.

Clement, A.C., Seager, R., Cane, M.A., 2000. Suppression of El Niño during the mid-Holocene by changes in the Earth's orbit. Paleoceanography 15 (6), 731-737.

Dean, W.E., in press. The geochemical record of the last 17,000 years in the Guaymas Basin, Gulf of California. Chem. Geol.

Dean, W.E., Forester, R.M, Bradbury, J.P., 2002. Early Holocene change in atmospheric circulation in the Northern Great Plains: an upstream view of the 8.2 ka cold event. Quat. Sci. Rev. 21, $1763-1775$.

Diffenbaugh, N.S., Sloan, L.C., 2004. Mid-Holocene orbital forcing of regional-scale climate: a case study of western North America using a high-resolution RCM. J. Climate 17 (15), 2927-2937.

Ely, L.L., Enzel, Y., Baker, V.R., Cayan, D.R., 1993. A 5000-year record of extreme floods and climate change in the Southwestern United States. Science 262, 410-412.

Engleman, E.E., Jackson, L.L., Norton, D.R., Fischer, A.G., 1985. Determination of carbonate carbon in geological materials by coulometric titration. Chem. Geol. 53, 125-128.

Ganeshram, R.S., Pedersen, T.F., 1998. Glacial-interglacial variability in upwelling and bioproductivity off NW Mexico: implications for quaternary paleoclimate. Paleoceanography 13, 634-645.

Goodfriend, G.A., Flessa, K.W., 1997. Radiocarbon reservoir ages in the Gulf of California: roles of upwelling and flow from the Colorado River. Radiocarbon 39, 139-148.

Haug, G.H., Hughen, K.A., Sigman, D.M., Peterson, L.C., Röhl, U., 2001. Southward migration of the Intertropical Convergence Zone through the Holocene. Science 293, 1304-1308.

Keigwin, L.D., 2002. Late Pleistocene-Holocene paleoceanography and ventilation of the Gulf of California. J. Oceanogr. 58, 421-432.

Keigwin, L.D., Jones, G.A., 1990. Deglacial climatic oscillations in the Gulf of California. Paleoceanography 5 (6), 1009-1023.

Kemp, A.E.S., Pike, J., Pearce, R.B., Lange, C., 2000. The "Fall dump"- a new perspective on the role of a "shade flora" in the annual cycle of diatom production and export flux. Deep-Sea Res. II 47, 2129-2154.

Kennett, J.P., Ingram, B.L., 1995. A 20,000-year record of ocean circulation and climate change from the Santa Barbara basin. Nature 377, 510-514. 
Koutavas, A., Lynch-Stieglitz, J., Marchitto Jr, T.M., Sachs, J.P., 2002. El Niño-like pattern in ice age tropical Pacific sea surface temperature. Science 297, 226-229.

Mitchell, D.L., Ivanova, D., Rabin, R., Redmond, K., Brown, T.J., 2002. Gulf of California sea surface temperatures and the North American monsoon: mechanistic implications from observations. J. Climate 15, 2261-2281.

Mortlock, R.A., Froelich, P.N., 1989. A simple method for the rapid determination of biogenic opal in pelagic marine sediments. Deep Sea Res. 36, 1415-1426.

Moy, C.M., Seltzer, G.O., Seltzer, D.T., Anderson, D.M., 2002. Variability of El Niño/Southern Oscillation activity at millennial time scales during the Holocene epoch. Nature 420 (6912), $162-165$.

Murray, D., Schrader, H.J., 1983. Distribution of silicoflagellates in plankton samples from the Gulf of California. Mar. Micropaleontol. 7, 517-539.

Pares-Sierra, A., Mascarenhas, A., Marinone, S.G., Castro, R., 2002. Temporal and spatial variation of surface winds in the Gulf of California. Geophys. Res. Lett. 30 (6), 1312.

Pike, J., Kemp, A.E.S., 1997. Early Holocene decadal-scale ocean variability recorded in Gulf of California laminated sediments. Paleoceanography 12 (2), 227-238.

Pride, C., Thunell, R., Sigman, D., Keigwin, L., Altabet, M., Tappa, E., 1999. Nitrogen isotopic variations in the Gulf of California since the last deglaciation: response to global climate change. Paleoceanography 14 (3), 397-409.

Poelchau, H.S., 1976. Distribution of Holocene silicoflagellates in North Pacific sediments. Micropaleontology 22 (2), 164-193.

Polyak, V.J., Asmerom, Y., 2001. Late Holocene climate and cultural changes in the southwestern United States. Science, $294,148-294,151$.

Sancetta, C., 1995. Diatoms in the Gulf of California: seasonal flux patterns and the sediment record for the last 15,000 years. Paleoceanography 10 (1), 67-84.

Sandweiss, D.H., Maasch, K.A., Burger, R.L., Richardson III, J.B., Rollins, H.B., Clement, A., 2001. Variation in Holocene El Niño frequencies: climate records and cultural consequences in ancient Peru. Geology 29, 603-606.

Santamaria-del-Angel, E., Alavrez-Borrego, S., Muller-Karger, F.E., 1994. Gulf of California biogeographic regions based on coastal zone color scanner imagery. J. Geophys. Res. 99 (C4), 7411-7421.

Schrader, H., Pisias, N., Cheng, G., 1986. Seasonal variation of silicoflagellates in phytoplankton and varved sediments in the Gulf of California. Mar. Micropaleontol. 10, 207-233.

Spaulding, W.G., 1991. A middle Holocene vegetation record from the Mojave Desert of North America and its paleoclimatic significance. Quat. Res. 35, 427-437.

Stott, L., Poulsen, C., Lund, S., Thunell, R., 2002. Super ENSO and global climate oscillations at millennial time scales. Science 297, 222-226.

Stuiver, M., Reimer, P.J., Bard, E., Beck, J.W., Burr, G.S., Hughen, K.A., Kromer, B., McCormac, F.G., Plicht, J., Spurk, M., 1998. INTCAL98 radiocarbon age calibration $24,000-0$ cal BP. Radiocarbon 40, 1041-1083.

Thunell, R.C., 1998. Seasonal and annual variability in particle fluxes in the Gulf of California. A response to climate forcing. Deep-Sea Res. I 45, 2059-2083.

Thunell, R.C., Pride, C., Tappa, E., Muller-Karger, F., 1994. Varve formation in the Gulf of California: insights from time series sediment trap and remote sensing. Quat. Sci. Rev. 12, 451-464.

Thunell, R.C., Pride, C., Ziveri, P., Muller-Karger, F., Sancetta, C., Murray, D., 1996. Plankton response to physical forcing in the Gulf of California. J. Plankton Res. 18, 2017-2026.

Van Devender, T.R., Burgess, T.L., Felger, R.S., Turner, R.M., 1990. Holocene vegetation of the Hornoday Mountains of northwestern Sonora, Mexico. Proc. S. Diego Soc. Nat. Hist. 2, $1-19$.

Waters, M.R., Haynes, C.V., 2002. Late Quaternary arroyo formation and climate change in the American Southwest. Geology 29 (5), 399-402. 